tysfakcjonujące. Ta teoria jest lepsza, która zawiera większy zbiór potencjalnych falsyfikatorów, czyli faktów, które mogłyby ją obalić. Cechą dobrej teorii jest jej wysoki stopień logicznego nieprawdopodobieństwa.

Odwołując się do tej - dość kontrowersyjnej zresztą - zasady można powiedzieć, że w naszym przypadku sprawdzania wiarygodności odczytania 7Q 5 propozycja O'Callaghana zawiera wiele potencjalnych falsyfikatorów, które nadają jej większy stopień prawdoupodobnienia, donec contraria demonstrentur 8.

Kraków

KS. JERZY CHMIEL

\title{
Michal Galas
}

\section{DUCHOWOŚĆ ŻYDÓW POLSKICH W PRACACH GERSHOMA SCHOLEMA 1}

Gershom Scholem (1897-1982) jest postacią unikalną i wyjątkową nie tylko jako badacz mistycyzmu żydowskiego, ale także jako osobowość, która wywarła ogromny wpływ na kształtowanie się poglądów i opinii dotyczących współczesnych wydarzeń w całym żydowskim świecie, w Izraelu w szczególności. Jednakże główne jego zainteresowanie koncentrowało się wokół historii mistycyzmu żydowskiego. Jego prace $\mathrm{w}$ tej dziedzinie stały się fundamentem dla współczesnych badań. Świadectwem doniosłości dokonań Scholema są między innymi: utworzenie The Gershom Scholem Center for Study of Jewish Mysticism and Kabbalah w Uniwersytecie Hebrajskim w Jerozolimie; liczne o nim publikacje oraz konferencje na temat jego badań i osoby; a od 1992 roku przyznaje się nagrody jego imienia za wybitne osiągnięcia w dziedzinie badań nad mistycyzmem żydowskim.

Niestety postać Gershoma Scholema i główne jego prace nie są dobrze znane polskim czytelnikom. Dotychczas ukazała się w Polsce

8 Streszczenie niniejszego artykułu, pod tym samym tytułem, ukazało się w czasopiśmie „Filomata” 429-30(1995)98'-100'.

1 Artykuł ten ukazal się pierwotnie w j. niemieckim: Die Mystik der polnischen Juden in Gersom Scholems Arbeiten - ein forschungsgeschichtlicher Überblick, „Judaica” 2 (1995), s. 97-102. 
tylko jedna jego książka ${ }^{2}$ oraz kilka artykułów ${ }^{3}$. Niniejszy przegląd dotyczy tych jego prac, które wiążą się z historią duchowości żydowskiej w Polsce.

I.

Badania historii kabały i mistycyzmu rozpoczął Scholem od poszukiwań, spisywania i analizowania wszelkich dostępnych mu kabalistycznych dzieł i opracowań. Wynikiem tej dziaałlności była Bibliographia Kabbalistica 4. Zawarł w niej także pozycje dotyczące Żydów w Polsce, również w języku polskim. Odnoszą się one do różnych mistycznych i mesjańskich idei i kierunków, XVI i XVII wiecznej kabały, ruchów Sabataja Cwi i Jakuba Franka oraz chasydyzmu. Niestety nie jest ona $\mathrm{w}$ tym zakresie kompletna, być może $\mathrm{z}$ powodu nieznajomości języka polskiego.

II.

Prace, które pozostawił po sobie Scholem, dotyczące kabały w Polsce, odnoszą się głównie do analizy wpływów luriańskiej doktryny. Luriańska kabała, szczególnie jej stosunek do mesjanizmu i interpretacja idei tikkun, w połączeniu ze spekulacjami dotyczącymi roku odkupienia, przygotowała podłoże dla sabataizmu. Nie poślednią rolę przypisywał kabalistom z Polski, rabbiemu Natanowi Spirze, rabbiemu Samsonowi ben Pesach z Ostropola, Naftalemu Bacharachowi, rabbiemu Yechielowi z Niemirowa i rabbiemu Izaakowi Reprowerowi, i innym.5 Scholem zwraca uwagę na związek pomiędzy mesjańskimi zaintresowaniami i spekulacjami tychże kabalistów, dotyczącymi mającego nastąpić odkupienia $\mathrm{w}$ roku $408=1648$, a historycznymi wydarzeniami roku 1648 i lat następnych - pogromami i martyrologią Żydów w czasie wojen z Chmielnickim i Szwedami. Twierdzi on, że to właśnie te mesjańskie spekulacje połączone $z$ historycznymi wydarzeniami stały się przyczyną rozbudzenia apokaliptycznych nastrojów i powodzenia późniejszego mesjańskiego ruchu Sabataja Cwi. Zadaje jednak pytanie dlaczego wobec tego ,mesjasz" nie wywodził się z Pol-

2 Judaizm: parę giównych pojęć, tłum. J. Zychowicz, PAT Kraków, 1989 oraz ,inter esse” Kraków 1991.

${ }^{3}$ M.in. Kryzys tradycji $w$ mesjanizmie żydowskim, tłum. J. Doktór, ,Literatura na Swiecie", 5-6 (1993), s. 42-81; Wiernośc i utopia, Brulion 23-24 (1994), s. 127-134; Walter Benjamin, tłum. J. Balbierz, ,Literatura na Swiecie" 3 (1995), s. 117-144.

4 Leipzig 1927; Berlin, 1933.

5 Por. rozdzial p.t., Kabbalis in Poland, w: Sabbatai Sevi. The Mystical Messiah 1626-1676, Princeton 1973, s. 77-92. 
ski? Scholem jest także autorem wielu artykułów i haseł dotyczących innych kabalistów i aspektów kabały w Polsce. Badania te zostały opublikowane w Encyclopaedia Judaica oraz w książce Kabbalah.6 Niestety nie opublikował on żadnej pracy dotyczącej kabały w Polsce po 1666 roku.

III.

Kolejną dziedziną zainteresowania Scholema, chyba najbardziej interesującą dla naszego tematu, były mistyczne ruchy mesjańskie, sabataizm i frankizm. Badania dotyczące tych ruchów stanowiły przelom $\mathrm{w}$ ich traktowaniu $\mathrm{w}$ żydowskiej historiografii. Pierwszą pracę, która wzbudziła ogromne zainteresowanie, ale i kontrowersje był artykuł opublikowany w 1937 roku Micwa ha-ba'ah be-'awerah (Odkupienie przez grzech) ${ }^{7}$. Scholem przedstawił $\mathrm{w}$ niej nową interpretację doktryn sabataizmu i frankizmu, bez ideologicznych i historycznych obciążeń, które dominowały we wcześniejszych pracach, chociażby przedstawicieli „Wissenschaft des Judentums”. Artykuł ten był sygnałem wielkiej zmiany w badaniach żydowskiej historii. W 1953 roku opublikował Scholem prace Ha-tnu'a ha-szabatait be-Polin (Ruch sabataistyczny $w$ Polsce) ${ }^{8}$ podzieloną na trzy części poświęcone: luriańskiej kabale, sabataizmowi i frankizmowi. Artykuł opublikowany został także po francusku 9 oraz włączony został do hebrajskiego wyboru źródeł i studiów dotyczących sabataizmu 10, jednakże został tam znacznie okrojony oraz zmienione zostały w nim (na gorsze) thumaczenia tekstów $\mathrm{z}$ j. polskiego ${ }^{11}$. Jednak prawdziwym epokowym dzielem była wspomniana już wcześniej monumentalna praca Sabbatai Sevi. The Mystical Messiah 1626-1676 12, do dzisiaj najpełniejsze opraopracowanie historii i doktryny ruchu Sabbataja Cwi. Dzieło to zawiera wiele materiału dotyczącego rozprzestrzeniania się sabataistycznej ideologii i opozycji w Polsce. Scholem opierał się na wszystkich możliwych do wykorzystania źródłach i opracowaniach, również w ję-

6 Jerusalem, 1974.

7 ,Keneset”, II, 1937, s. 347-92, opublikowana w 1992 roku także po niemiecku: Judaica 5: Erlösung durch Sünde, Herausgegeben, aus dem Hebräischen übersetzt und mit einem Nachwort versehen von Michael Brocke, Frankfurt am Main, 1992.

8 W: „Beit Israel be-Polin”, 1954, t. 2, s. 36-76.

9 Le mouvement sabbataiste en Pologne, ,Revue de l'histoire des religions", 143 (1953), s. 30-90, 209-232; 144 (1953), s. 42-77.

10 Studies and texts concerning the history of sabbetianism and its metamorphoses, (hebr.), Jerusalem 1982, s. 68-140.

11 Por. M. Galas, Sabbateanism in Polish Historiography, w: Proceedings of the 5th Congress of European Association for Jewish Studies, Copenhagen, 14-18 August 1994, (w druku).

12 Princeton 1973; także po niemiecku. 
zyku polskim. Dosyć często cytuje, choć niestety bezkrytycznie, prace Mejra Bałabana 13. W 1959 roku przebywał Scholem w Polsce, na zaproszenie prezesa Polskiej Akademii Nauk profesora Tadeusza Kotarbińskiego, i prowadził badania w Bibliotece Jagiellońskiej w Krakowie oraz w Żydowskim Instytucie Historycznym w Warszawie. Wyniki tych badań wykorzystał w wielu pracach, szczególnie tych dotyczących frankizmu.

IV.

Frankizm traktował on jako kontynuację sabataizmu w jego radykalnej formie. Studia nad frankizmem do czasu badań Scholema, dotyczyły głównie zagadnień dysput „talmudystów” z „kontrtalmudystami" w Kamieńcu Podolskim i we Lwowie w 1757 i 1759 roku, przyjęcia chrztu przez zwolenników Jakuba Franka oraz opozycji ortodoksji. Starano się minimalizować ideowe znaczenie frankizmu „wstydliwego" wydarzenia z historii Żydów. Scholema nie tyle interesowała historia ruchu, ile próbował raczej zrozumieć i przeanalizować doktrynę i ideologię ruchu, ze wszystkimi tego konsekwencjami. Jego zdaniem, właściwe zrozumienie ruchu frankistów polega na zrozumieniu nowego języka, którym się posługiwali. Mistyczny mesjanizm sabataistów bazował na skomplikowanych teozoficznych doktrynach kabalistycznej gnozy, były to pojęcia zrozumiałe tylko dla wąskiej grupy wtajemniczonych. Z chwilą gdy J. Frank powrócił do Polski i zaczął występować wśród swoich zwolenników jako prorok i mesjasz, odrzucił kabalistyczną terminologię i posługiwał się popularnym językiem i symbolami. Scholem wykazał także związki ideologii frankistowskiej, jak i samych frankistów, z europejskim oświeceniem, haskalą i Rewolucją Francuską. Do najważniejszych prac, dotyczących tego zagadnienia, trzeba zaliczyć Die Metamorphose des häretischen Messianismus der Sabbatianer in religiösen Nihilismus im 18. Jahrhundert 14 oraz artykuł Der Nihilismus als religioses Phänomen 15 . Ten ostatni artykuł został zamieszczony w wydanym po francusku wyborze prac Scholema zatytułowanym De la creation du monde jusqu'a Varsovie.16 G. Scholema interesowała również sprawa ewentualnych wpływów kultury polskiej i katolicyzmu na frankizm, szczególnie jeśli chodziło o pojawienie się idei Panny w doktrynie Franka oraz odwrotnie wpływów frankistowskich na mesjanistów polskich okresu

13 Szczególnie jego artykuł: Sabataism w Polsce: ustęp z „Dziejów mistyki żydowskiej w Polsce, w: Księga jubileuszowa ku czci prof. dr. Mojżesza Schorra, Warszawa 1935, s. $45-90$.

14 W: tegoż, „Judaica" 3, Frankfurt a./M., 1973, s. 198-217.

15 W: tegoż, „Judaica" 4, Frankfurt a./M., 1984, s. 129-189.

16 Paris, 1990. 
romantyzmu. Wielokrotnie wspomina w swoich pracach o Adamie Mickiewiczu i Andrzeju Towiańskim. O ogromnym zainteresowaniu tym zagadnieniem świadczy jego artykuł Julian von Brinkens Romanhafterzählung über die Frankisten ${ }^{17}$, który dotyczy historii frankistów w Warszawie w początkach XIX wieku. Scholem planował napisanie, wspólnie z Abrahamem G. Dukerem, większej pracy dotyczącej mesjanizmu żydowskiego w Polsce w XIX wieku. Niestety zamierzenia tego nigdy nie wykonał.

V.

Ostatnim tematem związanym $\mathrm{z}$ dziejami Żydów $w$ Polsce $\mathrm{i}$ badaniami Scholema jest chasydyzm. Scholem nie napisał pełnego opracowania historii chasadyzmu. Taką próbą ogólnego spojrzenia na ten ruch zaprezentował $\mathrm{w}$ ostatnim rozdziale najpopularniejszej swojej pracy Major Trends in Jewish Mysticism 18. Liczne studia Scholema dotyczą w zasadzie tylko początków tego ruchu do około 1815 roku 19 i koncentrują się na kilku problemach, najważniejsze $\mathrm{z}$ nich to: relacje między chasydyzmem a kabałą i między chasydyzmem a sabataizmem oraz rola mesjanizmu i idei dewekut w chasydyzmie. Dotyczyły one ruchu jako całości, a nie tylko historii chasydyzmu w Polsce. Scholem uważa, że chasydyzm nie był nową formą kabały, chociaż cadycy i chasydzi używali teologii kabalistycznej jako zasady i sposobu myślenia. Oryginalność chasydzkiej nauki widzi w zastosowaniu kabalistycznych misteriów do życia wewnętrznego człowieka, do jego psychologicznych procesów tu i teraz.

Scholem twierdził, że idea mesjańska w chasydyzmie nie została całkowicie wyeliminowana, tak jak twierdził M. Buber - zresztą nie zgadzał się $\mathrm{z}$ Buberem także $\mathrm{i} w$ innych sprawach 20 - ale też nie uważał, że wiara w przyjście mesjasza dostarczała chasydom głównej motywacji ich religijnego życia, tak jak tego chcieli niektórzy religijni syjoniści. Jego zdaniem chasydzi przeinterpretowali luriańską doktrynę „świętych iskier" w świetle idei dewekut - łączności, komunii z Bogiem.21 W związku z tym idea odkupienia, tikkun, która

$17 \mathrm{~W}$ : Hommage à Georges Vajda, Louvain 1980, s. 479-503.

18 New York 1941, rozdz. 9, Hasidim: The latest phase.

19 M. in. artykuły: The historical Image of Rabbi Israel Baal Shem Tov (hebr.), „Molad”, XVIII (1960), s. 335-56; New Material on Israel Loebel and his anti-hassidic polemics, (hebr.), ,Zion”, XX (1955), s. 73-81; The two first testimonies on the relations between hassidic groups and Baal Shem Tov, (hebr.), „Tarbiz”, XXV (1956), s. 228-240; i inne.

20 Por. jego, Martin Buber, $s$ Interpretation of Hasidism, w: The Messianic Idea in Judaism, New York 1971, s. 227-250.

${ }^{21} \mathrm{O}$ ewolucji idei dewekut patrz jego artykuł: Devekut, or Communion with God, w; The Messianic Idea..., dz. cyt., s. 203-227. 
zajmowała centralne miejsce w luriańskim schemacie, nie dotyczyła już światła jako całości, ale tylko indywidualnej duszy. Scholem uwa$\dot{z ̇ a}$, że w chasydyzmie doszło do neutralizacji mesjanizmu, ${ }^{22}$ ale ta jego koncepcja była bardzo mocno atakowana, zwłaszcza przez I. Tishbiego 23 .

VI.

Zaprezentowany przegląd prac dotyczących mistycyzmu i mesjanizmu wśród Źydów w Polsce, został ograniczony do głównych publikacji. Bibliografia prac G. Scholema 24 zawiera ponad 600 pozycji, a prace dotyczące religijnego życia polskich Żydów zajmują sporo miejsca. Studia Scholema posiadają ciągle fundamentalną wartość dla badaczy religijnej tradycji Żydów wschodnioeuropejskich. Jednakże należy do nich podchodzić bardzo uważnie, ze względu na: wybiórcze traktowanie tematów przez Scholema, mankamenty spowodowane brakiem bezpośredniej znajomości polskojęzycznych źródeł oraz postęp w badaniach.

Kraków

MICHAE GALAS

KOMENTARZE - REFLEKSJE - MATERIALY DUSZPASTERSKIE

\section{O. Hugolin Langkammer OFM}

\section{„SACRIS LITTERIS INITITUR” *}

W bulli dogmatycznej o Wniebowzięciu Najświętszej Maryi Panny czytamy, że ta prawda „sacris litteris inititur”. Zresztą wszystkie dogmaty - a także maryjne są zgodne z Objawieniem i z niego wypływają. Spójrzmy krótko na pierwszy i podstawowy dogmat maryjny, że Maryja jest Świętą Bożą Rodzicielką (Theotokos). Maryja „poczęła z Ducha Świętego", a więc za sprawą Boga, bez ingerencji mę-

22 Por., The Neutralization of the Messianic Element in Early Hasidism, w: The Messianic Idea..., dz. cyt., s. 176-202.

23 The Messianic Idea in the Rise of Hasidim (hebr.), „Zion" XXXII (1967), s. $1-45$. 1977.

${ }_{24}$ Bibliography of the Writings of Gershom G. Scholem, Jerusalem

* Homilia wygłoszona w czasie Mszy św. inaugurującej XXXII Sympozjum Polskich Biblistów w Częstochowie, w dniu 15.09.1994 r. 